\title{
Metode Geolistrik Konfigurasi Dipol-dipol untuk Identifikasi Daerah Patahan Manado di Kecamatan Singkil Kota Manado
}

As'ari a*, Seni H.J. Tongkukut a*

aJurusan Fisika, FMIPA, Unsrat, Manado

\begin{abstract}
A B S T R A K
Evaluasi potensi bencana gempa bumi membutuhkan data daerah sumber gempa yaitu daerah batas lempeng dan patahan-patahan aktif intra-lempengnya.Hambatan utama dalam evaluasi bahaya gempa yang bersumber di darat adalah keterbatasan data dari patahan aktif sebagai sumber gempa.Patahan Manado merupakan salah satu patahan di Sulawesi Utara, patahan ini menurut peta geologi melalui Kota Manado. Keberadaan patahan memerlukan identifikasi lebih lanjut menggunakan survei geofisika bawah permukaan. Penelitian bertujuan mengidentifikasi sifat Patahan Manado.Lokasi penelitian dilakukan di Kecamatan Singkil yang merupakan wilayah yang dilalui Patahan Manado. Eksplorasi dilakukan dengan menggunakan metode geolistrik tahanan jenis konfigurasi dipol-dipol. Data diolah dengan menggunakan perangkat lunak Res2dinv, dan dihasilkan tampang lintang resistivitas 2 dimensi bawah permukaan bumi. Patahan Manado di identifikasi sebagai rekahan dengan nilai resistivitas $\rho \leq 26 \Omega \mathrm{m}$. Pada lintasan 1 rekahan terletak di posisi elektroda 1 - 14, yaitu pada meter ke 5 - 70 dengan kedalaman 0 - 20 m. Pada lintasan 2 rekahan dijumpai pada elektroda 17 - 22,5 yaitu pada posisi meter ke 85 - 115 dengan kedalaman 0 - 16 m.
\end{abstract}

\section{A B S T R A C T}

KE Y W O R D S

fault, fractures, dipole-dipole

TERSEDIA ONLINE

01 Agustus 2016

\begin{abstract}
Evaluation of potential earthquake needs data source area which is the area of plate boundaries and active inter-plate faults. The main problem in the evaluation of seismic hazard that originates on land is limited data on active faults as the source of earthquake. Manado Fault is one fault in North Sulawesi, this fault according to the geological map through the city of Manado. The existence of a fault requires further identification using subsurface geophysical surveys. The research aims to identify the character of Manado fault. Location of research conducted in the District Singkil which is a region traversed Manado Fault. Exploration conducted by using geoelectric resistivity dipole-dipole configuration. The data were processed using the RES2DINV software, and the resulting cross section of the two-dimensional resistivity of the subsurface of the earth. Manado Fault identified as fractures or joint to the value of resistivity $\rho \leq 26 \Omega \mathrm{m}$. In path 1 fractures located at the position of electrodes 1-14, ie the meter to 5-70 with a depth of 0-20 m. In path 2 , fractures encountered in the electrode 17 to 22.5 meters that is in a position to $85-115$ at a depth of 0$16 \mathrm{~m}$.
\end{abstract}




\section{Pendahuluan}

Bencana alam gempa bumi antara lain adalah karena akibat langsung dari perekahan dan pergerakan dari patahan atau sesar yang terdapat di batas-batas lempeng bumi. Indonesia adalah negara kepulauan yang berada di batas pertemuan lempeng-lempeng besar dunia yaitu lempeng Eurasia di utara, Pasifik di timur dan Astralia di selatan. Kondisi geografis di batas pertemuan lempeng serta keberadaan patahan yang cukup banyak di wilayah Indonesia menyebabkan indonesia adalah negara dengan ancaman bencana gempa yang tinggi.

Patahan adalah sumber gempa darat yang termasuk langka dipetakan. Gempa yang bersumber di patahan akan memberikan dampak kerusakan yang besar khususnya pada kawasan yang dilalui patahan. Bangunan dan konstruksi yang didirikan persis di atas jalur patahan akan mendapat efek goncangan gempa paling keras ketika gempa terjadi. Struktur geologi menunjukkan bahwa wilayah utara pulau Sulawesi mempunyai beberapa patahan yaitu Patahan Gorontalo, Patahan Amurang, Patahan Mongondow dan Patahan Manado.Patahan tersebut merupakan sumber gempa yang sangat potensial terjadi di wilayah utara Sulawesi.

Patahan Manado yang melintasi wilayah Kotamadya Manado menurut Peta Geologi lembar Manado (Gamabar 1) diperkirakan berada pada lokasi tepat di bawah kota Manado-KetangSorengsong-Paslaten-Karegesan-Tontalete pada satu garis lurus (Effendi dan Bawono, 1997).

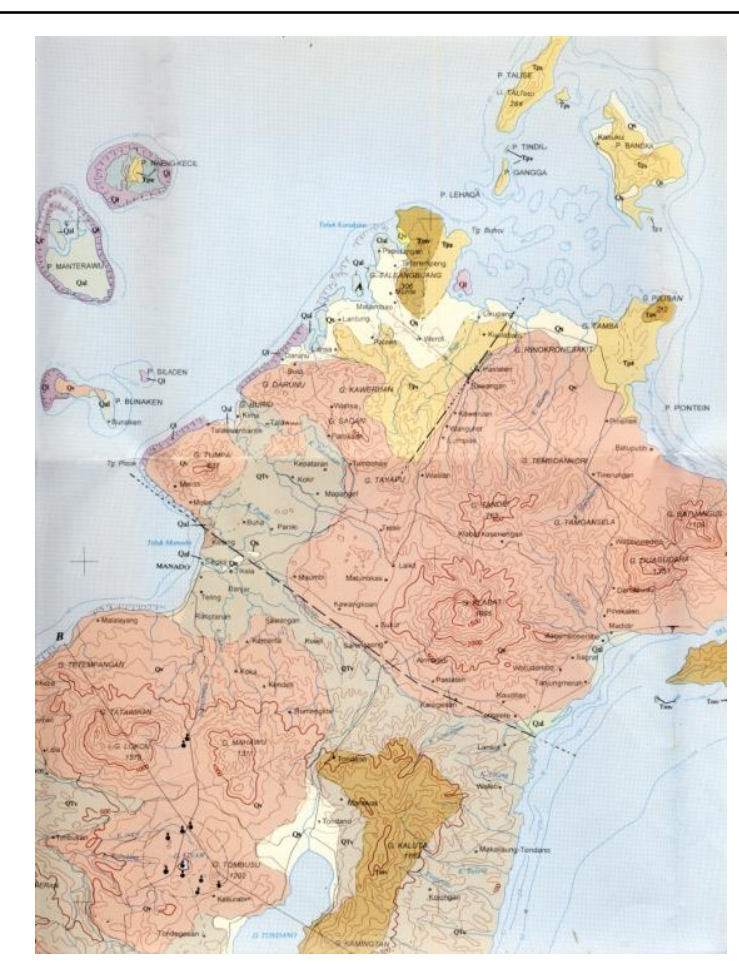

Gambar 1. Patahan Manado di wilayah Sulawesi Utara (Effendi dan Bawono, 1997).
Peta patahan aktif adalah peta garis/jejak pertemuan dari bidang patahan aktif di permukaan bumi. Kenampakan patahan di permukaan bumi dapat diidentifikasi dari berbagai macam bentukan morfologi alam (i.e morfotektonik) sebagai hasil interaksi antara proses pergerakan pada patahan dan proses-proses alam di permukaan bumi. Metode yang dapat membantu identifikasi dan pemetaan patahan aktif antara lain: (1) data geolog dan geofisika bawah permukaan, (2) indikasi keberadaan dan keaktifan patahan dari data catatan sejarah, (3) data seismik dan (4) data pergerakan tektonik muka bumi (dari rekaman GPS).

Pemetaan patahan aktif memerlukan keahlian khusus untuk melakukannya [Yeats, et al, 1997]. Penentuan lokasi persis dari patahan aktif di permukaan bumi tidak cukup hanya dilihat dari bentang alam dan geologi namun harus dibantu dengan survei geofisika bawah permukaan, seperti dengan metode: seismik refleksi resolusi tinggi, seismik refraksi, georadar dan metoda lainnya (Natawidjaya, 2007).

Wahyono, dkk., 2008 telah memetakan patahan di desa Renokenongo Kabupaten Sidoarjo melalui pengambilan data dengan metode DipolDipol yang diolah dengan perangkat lunak Res2dinv untuk mendapatkan tampilan 2D kontur resistivitas struktur lapisan tanah bawah permukaan. Survei geolistrik tahanan jenis pada umumnya bertujuan untuk mengetahui kondisi atau struktur geologi bawah permukaan berdasarkan variasi tahanan jenis batuannya. Struktur geolog yang dapat dideteksi dengan metoda ini terutama adalah yang mempunyai kontras tahanan jenis yang cukup jelas terhadap sekitarnya. As'ari, 2009, dengan menggunakan metode geolistrik konfigurasi Schlumberger telah memetakan kondisi paleomorphology di candi Prambanan dan sekitarnya, sehingga kondisi lapisan bawah permukaan dapat diketahui berdasarkan kontras resistivitas tanahnya.

Andriyani, dkk.2010 melakukan penelitian mengenai penelusuran system sungai bawah tanah dengan menggunakan metode geolistrik imaging konfigurasi dipol-dipol di kawasan karst Pacitan, Jawa Timur. Hasil penelitian ini menunjukkan bahwa: Hasil pengolahan data mapping menunjukkan pola kontur adanya sistem sungai bawah tanah.

Karakteristik gempa bumi antara lain adalah akibat gempa dapat menimbulkan bencana, berpotensi terulang kembali, belum dapat diprediksi, tidak dapat dicegah tetapi akibat yang ditimbulkannya dapat dikurangi. Faktor-faktor yang mengakibatkan kerusakan akibat gempa bumi adalah kekuatan gempa, kedalaman sumber gempa, jarak hiposentrum gempa, lama getaran gempa, kondisi tanah setempat dan konstruksi bangunan (www.Bmkg.co.id, 2012). Perambatan 
gelombang gempa bumi dipengaruhi oleh jenis batuan yang menjadi media perambatannya. Jenis batuan yang dilewati patahan Manado adalah batuan gunung api breksi, tufa, tuf, alluvium, batu gamping, terumbu koral, pasir, lanau, konglomerat dan lempung napalan. Sebagian wilayah di Sulawesi Utara merupakan wilayah dengan potensi gerakan tanah menengah-tinggi, terutama beberapa wilayah yang berada pada jalur Patahan Manado seperti Airmadidi dan Mapanget (DESDM, 2008).

Natawidjaya, 2007 menyatakan bahwa untuk menentukan lokasi persis suatu patahan aktif di permukaan, tidak cukup hanya dari bentang alam dan geologi tetapi harus dibantu dengan survei geofisika bawah permukaan seperti dengan metode : seismik refleksi resolusi tinggi, seismik refraksi, georadar, geolistrik dan metode lainnya. Utiya, dkk. 2015 mengeksplorasi keberadaan Patahan Manado Kecamatan Paaldua, Kota Manado, menggunakan metode geolistrik tahanan jenis konfigurasi Wenner-Schlumberger dan konfigurasi Dipol-dipol. Diperoleh hasil bahwa bidang-bidang lemah

pada lintasan 2 dan lintasan 4 dengan nilai resitivitas batuan berkisar (2,72-86) $\Omega \mathrm{m}$, memotong perlapisan antara batuan yang memiliki resistivitas yang lebih tinggi. Bidang lemah tersebut diperkirakan sebagai rekahan yang ditemukan pada kedalaman (2,50-40) meter dari permukaan tanah.Sekarang ini pada patahan Manado perlu dilakukan survei bawah permukaan untuk mengetahui sifat patahan Manado sebagai upaya mengurangi kerusakan dan kerugian akibat kejadian gempa.

Frans, dkk. 2015 melakukan identifikasi Patahan Manado di Kecamatan Singkil ,Identifikasi patahan menggunakan metode geolistrik tahanan jenis dengan konfigurasi Wenner- Schlumberger. Berdasarkan pengolahan dan analisis nilai resistivitas rendah ( $\rho<20,9 \Omega \mathrm{m}$ ) pada lintasan 1 , 2 , dan 3 yang memotong perlapisan antara batuan yang memiliki nilai resistivitas yang lebih tinggi bidang lemah cenderung terbuka pada bagian permukaan tanah yang diduga sebagai rekahan dengan kedalaman $(3-33,8)$ meter dari permukaan tanah. Dugaan keberadaan rekahan pada Patahan Manado di Kecamatan Singkil tersebut perlu diuji kembali dengan menggunakan metode geolistrik dengan konfigurasi dipol-dipol. Metode geolistrik tahanan jenis konfigurasi dipol-dipol dapat menggambarkan sifat rekahan dan akan digunakan untuk mengeksplorasi keberadaan rekahan tersebut.

\section{Material dan Metode}

Penelitian dilakukan di Kecamatan Singkil Kota Manado, pada koordinat (1030'34,63"1030'21,65")LU dan (124051'23,58". 124051'42,93")BT. Penelitian dilakukan pada bulan Maret - September 2016. Data geolistrik diperoleh dengan menggunakan alat multichannel and multielectrode resistivity and IP meter MAE X612EM. penelitian dilaksanakan di kecamatan Singkil dengan dua lintasan pengukuran dengan masing-masing lintasan terdiri dari 48 buah elektroda.

Jarak kedua lintasan 50 meter, lintasan 1 dengan spasi antar elektrode (a) 5 meter. Lintasan 2 diukur dengan menggunakan spasi antar elektroda $10 \mathrm{~m}$. Hasil pengukuran meliputi kuat arus (I), jarak spasi (a) dan resistivitas semu $(\rho)$ serta data ketinggian setiap elektroda yang diperoleh dari pengukuran menggunakan GPS.

Data hasil pengukuran diolah dengan menggunakan perangkat lunak Res2dinv, hasil olahan berupa gambar tampang lintang resistivitas dalam bentuk 2 dimensi (2D). Sifat patahan dapat dianalisis dan diperkirakan dari gambar tampang lintang pada kedua lintasan tersebut.

\section{Hasil dan Pembahasan}

Akuisisi data di lokasi penelitian dilaksanakan pada dua lintasan, Lintasan 1 dan Lintasan 2 dengan posisi lintasan tampak pada Gambar 2.

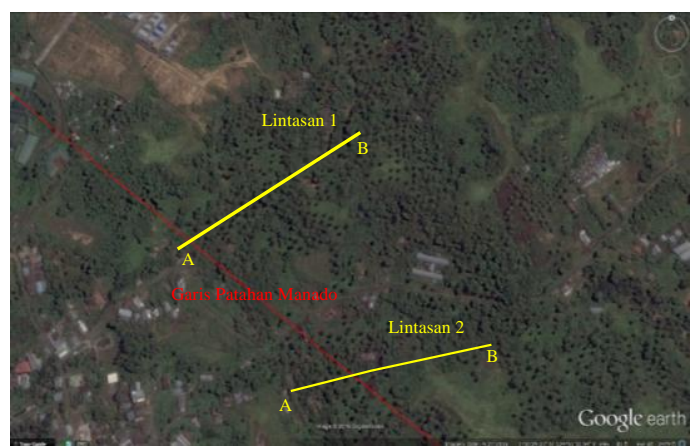

Gambar 2. Peta Lintasan akuisisi data pada lokasi penelitian

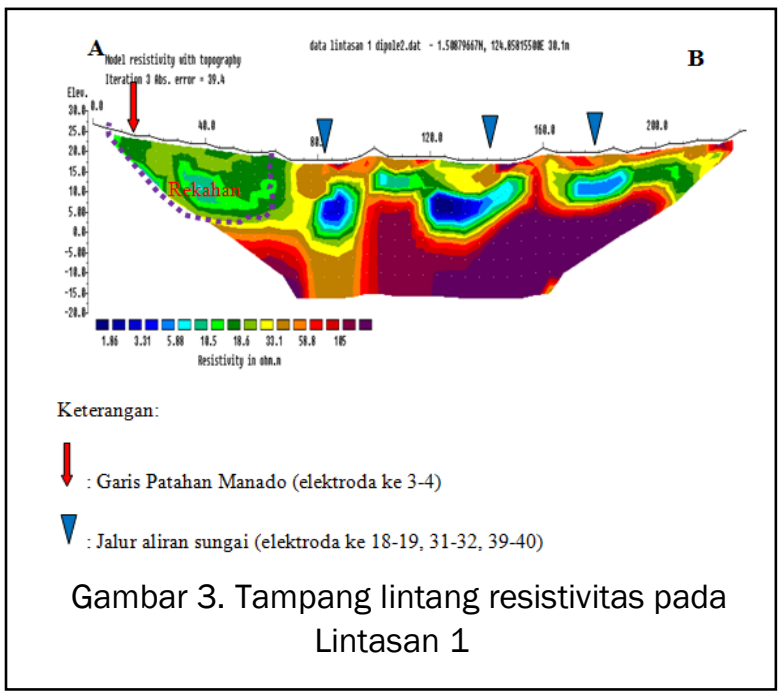

Gambar 3 menunjukkan hasil olahan pada lintasan 1, bidang lemah yang diindikasikan dengan resistivitas rendah dengan lemah $\rho \leq 26 \Omega \mathrm{m}$ 
terletak pada posisi elektroda 1 - 14. Posisi ini bertepatan dengan meter ke 5 - 70, dan garis lintasan 1 memotong garis Patahan Manado pada elektoroda 3 - 4 atau meter ke 15 - 20. Dilihat dari sifat bidang lemah yang mempunyai bentuk tak beraturan, bidang lemah ini menerus sampai permukaan dan tersusun oleh material yang relatif lebih konduktif dari pada batuan disekitarnya maka diduga sebagai rekahan. Rekahan mempunyai lebar $65 \mathrm{~m}$, menempati ruang dari permukaan ( 0 m) sampai kedalaman $20 \mathrm{~m}$.

Hasil ini mempunyai kemiripan dengan identifikasi yang dilakukan oleh Helen dkk, 2015 pada lokasi yang sama yang melakukan pendugaan dengan geolistrik konfigurasi Wenner-Schlumberger, diidentifikasi sebagai rekahan, $\rho<20,9 \Omega \mathrm{m}$, lebar $65 \mathrm{~m}$, kedalaman sampai 28,7 m Lokasi rekahan tepat pada garis Patahan Manado.

Hasil olahan untuk lintasan 2 diperlihatkan pada Gambar 4.

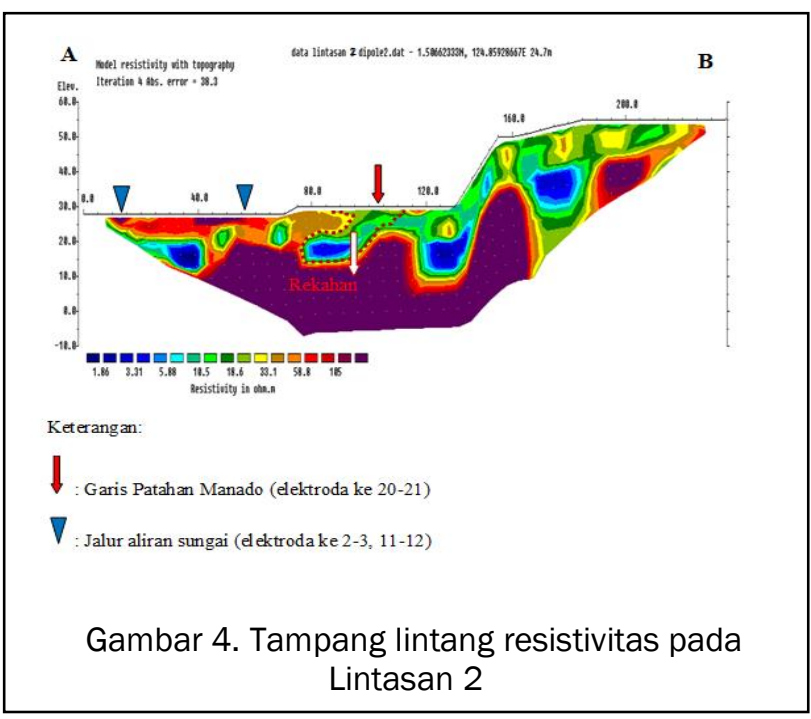

Lintasan 2 memotong garis Patahan Manado pada antara elektroda 20 - 21, bersesuaian dengan meter ke 100 - 105. Pada lokasi lintasan 2 diperoleh zona lemah $\rho<26 \Omega$ m pada elektroda 17 - 22,5, zona lemah pada lintasan 2 ini juga diidentifikasi sebagai rekahan karena mempunyai sifat yang sama dengan zona lemah pada lintasan 1. Rekahan mempunyai lebar $27,5 \mathrm{~m}$, menempati ruang dari permukaan sampai kedalaman $16 \mathrm{~m}$. Rekahan menempati posisi tepat pada garis Patahan Manado.

Hasil ini juga mempunyai kemiripan dengan identifikasi yang dilakukan oleh Frans dkk, 2015, yang melakukan pendugaan dengan geolistrik konfigurasi Wenner-Schlumberger, Patahan Manado pada peta Geologi diidentifikasi sebagai rekahan, $\rho$ $<20,9 \Omega \mathrm{m}$, lebar $30 \mathrm{~m}$, kedalaman sampai 19,8 m, dan lokasi rekahan tepat pada garis Patahan Manado.

\section{Kesimpulan}

1. Identifikasi Patahan Manado di Kecamatan Singkil menggunakan metode geolistrik resistivitas konfigurasi dipol-dipol, diperoleh bidang lemah $(\rho<26 \Omega \mathrm{m})$ memotong perlapisan batuan dengan resistivitas yang lebih tinggi. Bidang lemah diduga sebagai rekahan.

2. Rekahan terletak pada garis Patahan ManadoPada lintasan 1 rekahan terletak di posisi elektroda 1 - 14, yaitu pada meter ke 5 70 dengan kedalaman 0 - $20 \mathrm{~m}$. Pada lintasan 2 rekahan dijumpai pada elektroda 17 - 22,5 yaitu pada posisi meter ke 85 - 115 dengan kedalaman 0 - $16 \mathrm{~m}$.

\section{Daftar Pustaka}

Andriyani, S., Ari, H. R., Sutarno, Metode Geolistrik Imaging Dipole-Dipole digunakan unruk Penelusuran Sistem Sungai Bawah Tanah pada Kawasan Kars di Pacitan, Jawa Timur.Jurnal Ekosains Vol 2 No 1. Maret 2010

As'ari, 2009, Pemetaaan Paleo-Morfologi Abad VIII di Kompleks Candi Prambanan dengan Menggunakan Metode Geolistrik, Tesis, UGM Yogyakarta

BMKG, Gempa Bumi, http://www.bmkg.co.id, 2012 [25 Mei 2013]

Efffendi, A. C., Bawono, S. S., 1997, Peta Geologi Lembar Manado, Sulawesi Utara, Edisi ke-2 Pusat Penelitian dan Pengembangan Geologi, Bandung

Frans, H. S., As'ari, Tamuntuan, G. H. 2015. Identifikasi Patahan Manado dengan menggunakan Metode Geolistrik Knfigurasi Wenner-Schlumberger di Kota Manado. Jurnal IImiah Sains Vol 15 No 2 Oktober 2015 . Hal 142-148. Universitas Sam Ratulangi. Manado.

Natawidjaya, D. H., Evaluasi Bahaya Patahan Aktif, Tsunami dan Goncangan Gempa, Laboratorium Riset Bencana Alam Geoteknologi-LIPI

Utiya, J., As'ari, Seni, H. J. T., 2015. Metode Geolistrik Resistivitas Jenis Konfigurasi WennerSchlumberger dan Dipol-Dipol untuk Identifikasi Patahan Manado di Kecamatan Paaldua Kota Manado. Jurnal IImiah Sains Vol 15 No 2 Oktober 2015 . Hal 135-141. Universitas Sam Ratulangi. Manado. 